\title{
Pemanfaatan Asap Cair Tempurung Kelapa Sebagai Pestisida Organik Terhadap Mortalitas Ulat Grayak (Spodoptera Litura F.)
}

\author{
Ishak Isa ${ }^{1 *}$, Wenny J.A Musa ${ }^{2}$,Sity Wirid Rahman ${ }^{3}$ \\ ${ }^{1,2}$ Program Studi Kimia, FMIPA Universitas Negeri Gorontalo \\ ${ }^{3}$ Program Studi Pendidikan Kimia, FMIPA Universitas Negeri Gorontalo
}

\section{*Corresponding author:}

email: isi@ung.ac.id

Received: 18 March, 2019

Accepted: 19 March, 2019

Online : 20 March, 2019
Abstract. This study aims to determine the effect of the concentration of liquid smoke coconut shell on mortality against armyworm. Research conducted at the Chemical Laboratory of the State University of Gorontalo. Liquid smoke is obtained through the pyrolysis process is a heating process at a given temperature of a coconut shell with a limited amount of oxygen. To find out the components contained in the liquid smoke coconut shell, then analyzed using GCMS, then in assay acid, phenol content test, test the $\mathrm{pH}$ of liquid smoke and liquid smoke test results influence coconut shell can be mortality in armyworm. The results obtained pyrolysis liquid smoke grade 3 is used as an organic pesticide on armyworms with a variant of the concentrations used are 1, 3, 5 and 7\%. GCMS analysis finds that there are 7 compound, methyl ester of oxalic acid 31.41\%, 2,3-butanadion 0.29\%, 48.75\% acetic acid, 2propanone 1-hydroxy 7.25\%, propanoic acid 4,01\%, 2furankarboksaldehid $5.09 \%$, and $3.19 \%$ phenol. Values acid test of $13.9356 \mathrm{mg} / \mathrm{mL}$, the test value phenol content of $6.537 \times 10^{-01} \%$, has a $\mathrm{pH}$ of 3. The results showed that liquid smoke coconut shell with a concentration of $7 \%$ have a presentation armyworm mortality of $88.89 \%$.

Keywords: Shell Oil, Liquid Smoke, Pesticides Organic, armyworm

\begin{abstract}
Abstrak. Penelitian ini bertujuan untuk mengetahui pengaruh konsentrasi asap cair tempurung kelapa terhadap mortalitas terhadap ulat grayak. Penelitian dilakukan di Laboratorium Kimia Universitas Negeri Gorontalo. Asap cair diperoleh melalui proses pirolisis merupakan proses pemanasan pada temperatur tertentu dari tempurung kelapa dengan jumlah oksigen yang terbatas. Untuk mengetahui komponen yang terdapat pada asap cair tempurung kelapa, maka dianalisis menggunakan GCMS, selanjutnya di uji kadar asam, uji kadar fenol, uji pH asap cair dan uji pengaruh hasil asap cair tempurung kelapa dapat bersifat mortalitas pada ulat grayak. Hasil pirolisis yang didapatkan asap cair grade 3 yang digunakan sebagai pestisida organik pada ulat grayak dengan varian konsentrasi yang digunakan yaitu 1, 3, 5 dan 7\%. Hasil analisis GCMS diketahui terdapat 7 senyawa, metil ester asam oksalat 31,41\%, 2,3-butanadion 0,29\%, asam asetat 48,75\%, 1 hidroksi- 2-propanon 7,25 \%, asam propanoat 4,01\%, 2-furan karboksaldehid 5,09\%, dan fenol 3,19\%. Nilai uji kadar asam sebesar $13,9356 \mathrm{mg} / \mathrm{mL}$, nilai uji kadar fenol sebesar $6,537 \times 10^{-01} \%$, memiliki $\mathrm{pH}$ sebesar 3. Hasil penelitian menunjukan bahwa asap cair tempurung kelapa dengan konsentrasi $7 \%$ memiliki presentasi mortalitas ulat grayak sebesar $88,89 \%$.
\end{abstract}

Kata Kunci : Tempurung kelapa, asap cair, pestisida organik, ulat grayak

\section{PENDAHULUAN}

Pestisida merupakan substansi kimia dan bahan lain yang digunakan untuk mengendalikan berbagai hama. Bagi petani jenis hama dan tumbuhan pengganggu, penyakit tanaman yang disebabkan oleh fungi (jamur), bakteria, dan virus, nematode (cacing yang merusak akar), ulat, siput, tikus, burung da hewan lain yang dianggap 
merugikan (Djojosumarto, 2008). Pestisida yang terdapat pada tanaman dapat terserap bersama hasil panen berupa residu yang dapat terkonsumsi oleh konsumen. Residu pestisida adalah zat tertentu yang terkandung dalam hasil pertanian bahan pangan atau pakan hewan, baik sebagai akibat langsung maupun tidak langsung dari penggunaan pestisida. Istilah ini mencakup juga senyawa turunan pestisida, seperti senyawa hasil konversi, metabolit, senyawa hasil reaksi dan zat pengotor yang dapat bersifat toksik (Sakung, 2004). Pestisida organik yang berasal dari tumbuhan disebut pula dengan pestisida nabati. Pestisida Nabati adalah pestisida yang bahan dasarnya berasal dari tumbuhan. Penggunaan pestisida nabati selain dapat mengurangi pencemaran lingkungan, harganya relatif lebih murah apabila dibandingkan dengan pestisida kimia (Sudarmo,2005). Contoh tumbuhan yang dapat digunakan sebagai pestisida yaitu tumbuhan kelapa, menurut Grimwood (1975), tempurung kelapa dikategorikan sebagai kayu keras, tetapi mempunyai kadar lignin lebih tinggi dan kadar selulosa lebih rendah.

Berdasarkan penelitian yang dilakukan oleh Trenggono (1996) yaitu membuat pestisida menggunakn metode Pirolisa, dengan hasil prodak asap cair tempurung kelapa, dimana terdapat sejumlah senyawa yang sangat beracun bagi serangga pemakan tumbuhan yakni, senyawa fenol 4,13\%, karbonil $1,30 \%$ dan keasaman $10,2 \%$. Adanya kandungan senyawasenyawa kimia di dalam asap cair tempurung kelapa yang terkandung dapat mematikan organisme pengganggu. Berdasarkan penelitian yang dilakukan oleh Luditama (2006), kualitas asap cair, yaitu fenol dan asam asetat, dari asap cair tempurung kelapa masing-masing sebesar $19,23 \%$ dan $128,13 \%$.

Ulat grayak, merupakan, Ulat grayak aktif makan pada malam hari, meninggalkan epidermis atas dan tulang daun sehingga daun yang terserang dari jauh terlihat berwarna putih (Balitbang, 2006). Larva yang masih kecil merusak daun dan menyerang secara serentak berkelompok. dengan meninggalkan sisa-sisa bagian atas epidermis daun, transparan dan tinggal tulang-tulang daun saja. Biasanya larva berada di permukaan bawah daun, umumnya terjadi pada musim kemarau (Tenrirawe dan Talanca, 2008). Selain pada daun, ulat dewasa makan polong muda dan tulang daun muda, sedangkan pada daun yang tua, tulang-tulangnya akan tersisa. Selain menyerang kedelai, ulat grayak juga menyerang jagung, kentang, tembakau, kacang hijau, bayam dan kubis (Balitbang, 2006).

\section{BAHAN DAN METODE PENELITIAN}

Penelitian ini dilaksanakan di Laboratorium Kimia Fakultas Matematika dan IImu Pengetahuan Alam Universitas Negeri Gorontalo.

Peralatan yang digunakan adalah pembuat arang, termometer, $\mathrm{pH}$ meter, kaca arloji, gelas piala, tabung reaksi, pipet tetes, labu ukur, spektrofotometer, neraca analitik, 1 set alat titrasi dan GC-MS.

Bahan baku yang utama penghasil asap cair adalah tempurung kelapa yang telah dihancurkan dalam bentuk kecil, untuk bahan analisis digunakan akuades, $\mathrm{KBrO}_{3}, \mathrm{KBr}, \mathrm{HCl}, \mathrm{KI}$, Indikator amylum, $\mathrm{Na}_{2} \mathrm{~S}_{2} \mathrm{O}_{3}$, Indikator universal, indikator phenolphthalein, dan $\mathrm{NaOH} 0,1 \mathrm{~N}$, Diklorometan.

\section{Pembuatan Asap Cair Tempurung Kelapa}

Alat yang digunkan dalam pembuatan asap cair merupakan modifikasi alat yang dilengkapi dengan kondensor dan satu tempat penampung asap cair. Uap yag terbentuk pada pembakaran mengalir mengikuti pipa hingga ke alat pendingin, asap yag telah menjadi cair dari proses pendinginan akan keluar melalui pipa yang kemudian ditampung pada suatu tempat penampung. Hasil asap cair ini kemdian didiamkan selama 24 jam untuk mengendapkan tar.

\section{Analisis Komponen Asap cair Menggunakan GCMS (Oramahi, H,A,. dkk 2010)}

Analisa senyawa-senyawa penyusun asap cair secara kualitatif dengan menggunakan GC-MS yaitu: asap cair diekstrak dengan menggunakan pelarut diklorometan, ke dalam 5 $\mathrm{mL}$ asap cair ditambah $5 \mathrm{~mL}$ diklorometan kemudian dikocok dengan corong pemisah selama 5 menit. Setelah didiamkan sebentar fraksi atas (diklorometan) dipisahkan dari fraksi bawah. Kemudian fraksi atas ditampung dan kedalam fraksi bawah ditambahkan $5 \mathrm{~mL}$ diklorometan, dikocok lagi dalam corong pemisah seperti yang pertama. Fraksi atas yang dihasilkan ekstraksi kedua ini dicampurkan dengan fraksi atas hasil pemisahan yang pertama, kemudian dipekatkan dengan meniupkan gas Nitrogrn sampai volume yang berisi $1 \mathrm{~mL}$. hasil tersebut 
kmudian dideteksi meggunakan GC-MS dengan kondisi operasi: jenis pengion: El (Elektron Impact), suhu injector: $310^{\circ} \mathrm{C}$, jenis kolom: Agilent HP 1 MS dengan panjang

$30 \mathrm{~m}$, suhu kolom $60^{\circ} \mathrm{C}$ dengan kenaikan $5^{\circ} \mathrm{C} /$ menit, gas pembawa: Helium dengan tekanan $13.0 \mathrm{kPa}$.

\section{Uji Kandungan Asam Asap cair (Metode titrasi-Prasetyowati, dkk. 2014)}

Kandungan total asam asap cair tempurung kelapa ditetapkan dengan metode titrasi asam basa (alkalimetri) dengan indikator phenolftalein. Asap cair dengan konsentrasi 13 , 5 , dan 7\%, diambil masing-masing $1 \mathrm{~mL}$ ditambahkan aquades sampai volume $100 \mathrm{ml}$ kemudian dicampur sampai homogen, larutan ini diambil $20 \mathrm{ml}$ dan ditambahkan 3 tetes indikator PP. Titrasi dengan $\mathrm{NaOH} 0,1 \mathrm{~N}$ sampai berwarna merah muda. Kandungan asam dihitung menggunakan persamaan 1 .

Kandungan asam $=\frac{\mathrm{V} \times \mathrm{N} \times \mathrm{BM}}{\mathrm{mL} \text { Sampel }}$

\section{Uji Kandungan Fenol Asap Cair (Metode titrasi-AOAC, 1990)}

Anaisis kandungan fenol, menggunakan metode titrasi, dibuat larutan 1, 3,5 dan $7 \%(\mathrm{v} / \mathrm{v})$, kemudian diambil $5 \mathrm{~mL}$ larutan selanjutnya ditambahkan $5 \mathrm{~mL} \mathrm{KBrO}_{3} 0,1 \mathrm{~N}, 0,2 \mathrm{~g} \mathrm{KBr}$, dan 3 $\mathrm{mL} \mathrm{HCl} 3 \mathrm{~N}$. Kemudian larutan diaduk dan didiamkan selama 30 menit lalu ditambahkan $\mathrm{KI}$ $0,2 \mathrm{~g}$ dititrasi dengan $\mathrm{Na}_{2} \mathrm{~S}_{2} \mathrm{O}_{3}$ sampai larutan berwarna kuning terang kemudian ditambahaan dengan indicator amylim, dan kemudian larutan dititrasi kembali sampai warna biru hilang.

$$
\begin{aligned}
\% \text { Fenol } & =\frac{(\mathrm{b}-\mathrm{a}) \times(\mathrm{BMf} / 6) \times 1000}{0,1 \times \text { bobot sampel }} \times 100 \% \\
\text { Keterangan: } & \\
\mathrm{b} \quad & =\text { Volume Blanko } \\
\mathrm{a} & =\text { Volume Contoh } \\
\mathrm{BMf} & =\text { Berat molekul Fenol } \\
6 & =\text { Jumlah atom brom yang dipakai }
\end{aligned}
$$

\section{Uji pH Asap cair (AOAC, 1995)}

Analisis $\mathrm{pH}$ dilakukan dengan cara mencelupkan indikator universal dalam asap cair, diamati warna indikator universal.

Uji Mortalitas Asap cair (Suhariyah, dkk. 2013)
Asap cair hasil pirolisis dibuat dalam 4 variasi konsentrasi $1 \%, 3 \%, 5 \%$, dan $7 \%$, kemudian ditempatkan di dalam botol semprot. Sebanyak 20 ekor ulat grayak dipreparasi selama \pm 5 jam tanpa makan, hal ini dilakukan untuk mengetahui apakah ulat grayak benar-benar mati karena senyawa dalam asap cair. Setealah \pm 5 jam, sebanyak 3 ekor ulat grayak ditempatkan pada wadah kaca yang bersih kemudian diberi makan rambut jangung yang telah disemprotkan 4 variasi konsentrasi sebnyak 2 kali, terdapat kontol yang hanya disemprotkan aquadest. Dilakukan penamatan dalam 24 jam, dan diulang sebanyak 3 kali. Persentase mortalitas dihitung dengan persamaan 3.

$\%$ Mortatalitas $=\frac{\mathrm{R} 1-\mathrm{R} 2}{\mathrm{R} 1} \times 100 \%$

R1 dan R2 adalah jumlah ulat grayak hidup sebelum dan setelah pengujian.

\section{HASIL DAN PEMBAHASAN}

\section{Pembuatan Asap Cair Tempurung Kelapa}

Bahan baku yakni tempurung kelapa dibersihkan terlebih dahulu sebelum dibakar, tempurung kelapa dipisahkan dari serabut kelapa, kemudian diperkecil ukurannya. Kemudian tempurung kelapa dimasukkan ke dalam alat pembakanran untuk dibakar. Pembakaran dilakukan dengan tidak sempurna yakni hanya memakai oksigen dalam jumlah yang sedikit, oksigen ini hanya untuk memancing adanya api untuk membakar tempurung kelapa, saat api sudah menyala kemudian disekat. Pembakaran dilakukan dalam kurung waktu 6-8 jam perhari dengan suhu $400^{\circ} \mathrm{C}$. Menurut Mega (1988) suhu yang tinggi pada proses pembakaran menghasilkan senyawa-senyawa dari 3 komponen yakni, selulosa, hemiselulosa dan lignin.

\section{Hasil Analisis Komponen Asap cair Menggunakan GCMS}

Hasil analisis dengan kromatografi gas untuk asap cair tempurung kelapa dari hasil pirolisis menghasilkan 7 puncak (peak). Kromatogram GC asap cair disajikan pada gambar 1.

Berdasarkan hasil analisis seperti pada gambar 1 terdapat 7 puncak yang menandakan terdapat 7 spektrum senyawa yang ada pada asap cair tempurung kelapa grade 3 hasil pirolisis. Hasil spektrum dapat tersaji pada Tabel 1. 


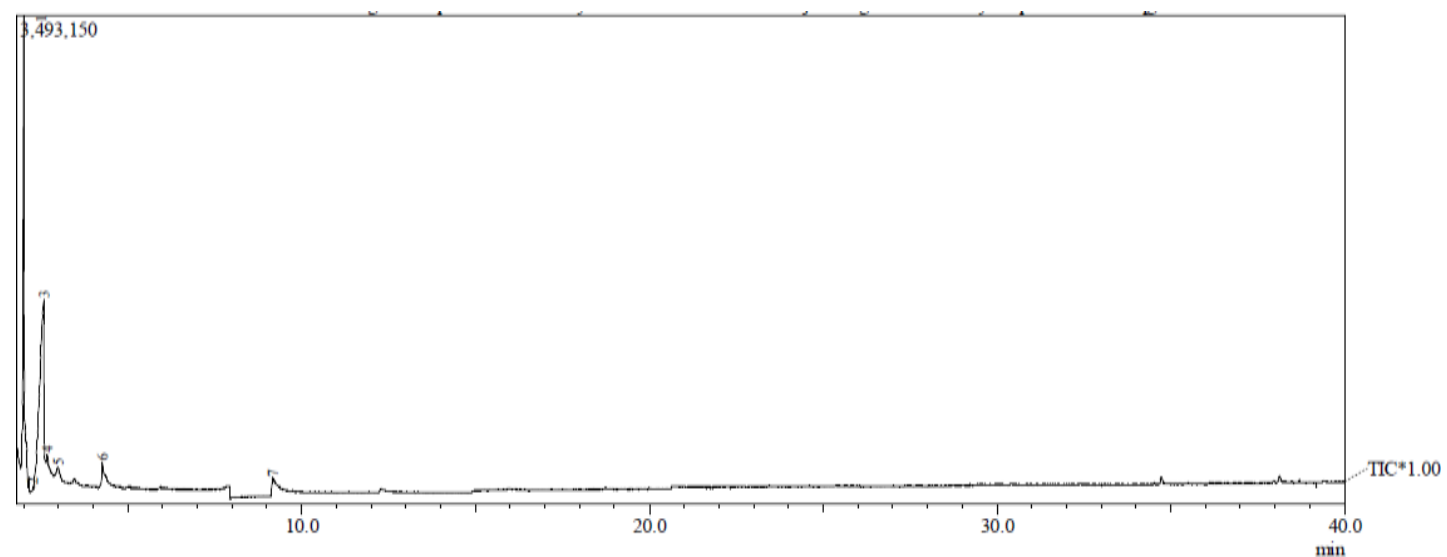

Gambar 1. Kromatogram GC Asap Cair Tempurung Kelapa

Tabel 1 Spektrum Massa Asap Cair Tempurung Kelapa Grade 3

\begin{tabular}{cccc}
\hline Peak & tR (menit) & Area\% & Nama Senyawa \\
\hline 1 & 2.003 & 31.41 & Metil Ester Asam Oksalat \\
2 & 2.275 & 0,29 & 2,3-Butanadion \\
3 & 2.580 & 48,75 & Asam Asetat \\
4 & 2.687 & 7,25 & 1-Hidroksi-2-Propanon \\
5 & 2.991 & 4,01 & Asam Propanoat \\
6 & 4.267 & 5,09 & 2-Furan Karboksaldehid \\
7 & 9.117 & 3,19 & Fenol
\end{tabular}

\section{Uji Kandungan Asam Asap cair}

Kandungan asam yang terdapat pada asap cair grade 3 berbeda pada setiap varians larutan uji. Kandungan asam asetat pada setiap varians larutan uji, semakin tinggi konsentrasi maka semakin besar pula kandungan asamnya. Kandungan asam pada berbagai konsentrasi asap cair dilihat pada Tabel 2.

Pada hasil penelitian kandungan asam asap cair tempurung kelapa memiliki nilai yang sangat besar dari hasil penelitian terdahulu oleh Hartati (2015), yang kandungan asam pada asap cair tempurung kelapa bernilai $8,40 \%$. Menurut Girard (1992), kandungan asap cair yang utama adalah asam asetat yang dihasilkan oleh pirolisa selulosa. Pemecahannya terjadi dalam dua tahap yaitu reaksi hidrolisis selulosa menjadi glukosa kemudian dengan pirolisa menjadi asam-asam, air, furan dan fenol.

Bahan yang kandungan selulosa yang tinggi akan menghasilkan total asam yang tinggi pula. Hasil dari penelitian Mega (1988) asam memiliki 2,8-4,5 dalam kandungan kimia dari asap cair tempurung kelapa grade 3 ,tempurung kelapa, kelembaban dan umur tempurung kelapa, temperature pirolisis, serta jumlah oksigen dalam pembakaran (Mega, 1987).

Tabel 2 Kandungan asam pada Asap Cair Tempurung Kelapa Grade 3

\begin{tabular}{ccc}
\hline No. & Konsentarsi \% (v/v) & Kandungan asam $(\mathbf{m g} / \mathbf{m L})$ \\
\hline 1. & 1 & 3,3516 \\
2. & 3 & 7,2912 \\
3. & 5 & 10,8780 \\
4. & 7 & 13,9356 \\
\hline
\end{tabular}

\section{Hasil Kandungan Fenol Asap cair}

Pada Tabel 3, pada penelitian ini hasil kandungan fenol memiliki nilai yang kecil, dimana penelitian sebelumnya menyebutkan kandungan fenol mencapai 0,2-2,9\% (Fatimah, 1998). Hal ini dikarenakan kurang optimalnya temperatur pirolisis sehingga lignin pada tempurung belum efektif terurai sempurna. Kandungan fenol ini sangat sedikit bila dibandingkan dengan kandungan asam asetat. Hal ini dapat dikarenakan degradasi lignin lebih sulit dari pada degradasi selulosa, walaupun kandungan lignin dan selulosa tidak jauh bebeda. 
Tabel 3. Kandungan fenol pada Asap Cair Tempurung Kelapa Grade 3

\begin{tabular}{ccc}
\hline No. & Konsentarsi \% (v/v) & Kandungan fenol $(\%)$ \\
\hline 1. & 1 & $1.569 \times 10^{-01}$ \\
2. & 3 & $2,092 \times 10^{-01}$ \\
3. & 5 & $4,184 \times 10^{-01}$ \\
4. & 7 & $6,537 \times 10^{-01}$ \\
\hline
\end{tabular}

\section{Hasil Uji pH Asap cair}

Pengujian $\mathrm{pH}$ asap cair tempurung kelapa menggunakan indikator universal. Dimana asap cair diambil sebanyak $1 \mathrm{~mL}$ kemudian diukur $\mathrm{pH}$ dengan mencelupkan indikator universal, perbedaan hasil ini dapat disebabkan karena perbedaan jenis dan varietas hasil yang didapatkan dimana asap cair memiliki pH 3. Hasil penelitian ini memenuhi standar mutu asap cair spesifikasi jepang karena memenuhi kisaran nilai pH 1,50-3,70 (Alpian, dkk 2013). Harga pH ini menandakan bahwa asap air tempurung kelapa bersifat asam. Harga $\mathrm{pH}$ akan semakin turun dengan semakin meningkatnya temperatur dan lama pembakaran. Hal ini dikarenakan semakin banyaknya unsur-unsur dalam tempurung kelapa yang terurai membentuk senyawa kimia yang bersifat asam. Dengan kecilnya nilai $\mathrm{pH}$ yang didapat akan memperlambat pertumbuhan mikroorganisme (Buckle, dkk.1985).

\section{Hasil Uji Mortalitas Asap cair}

Hasil uji mortalitas uat grayak dari asap cair tempurun kelapa grade 3 memiliki hasil tingkat rata-rata mortalitas dengan control 33,33; konsentrasi $1 \%$ sebesar44.44; konsentrasi 3\% sebesar 55.56; konsentrasi $5 \%$ sebesar 77.78 ; dan konsentrasi $7 \%$ sebesar 88.89 . Dari hasil dapat terlihat bahwa konsentrasi yang lebih kecil akan memberikan hasil toksisitas lebih sedikit untuk uji mortalitas, sedangkan konsentrasi yang lebih tinggi akan memberikan hasil toksisitas yang lebih besar.

Efek mortalitas yang terjadi diduga disebabkan oleh kandungan dari senyawa yang terdapat pada asap cair yang dapat berfungsi sebagai antimakan, dan racun. Mekanisme kerja adalah asap cair yang telah terlebih dahulu di semprotkan pada siklig masuk ke dalam tubuh ulat grayak yang dimakan selama 24 jam. Ulat grayak mati dikarenakan racun yang masuk melalui rambut jagung yang kemudian di dalam sel tubuh ulat grayak menghambat metabolisme sel yang menghambat transport elektron dalam mitokondria sehingga pembentukan energi dari makanan sebagai sumber energi dalam sel tidak terjadi dan sel tidak dapat beraktifitas, sehingga ulat grayak mati.

\section{KESIMPULAN}

Dari hasil penelitian yang dilakukan, maka dapat diambil kesimpulan sebagai berikut:

1. Asap cair tempurung kelapa grade 3 mengandung 7 komponen yang terdeteksi dengan spektrometer massa yakni, Metil Ester Asam Oksalat, 2,3-Butanadion, Asam Asetat, 1-Hidroksi-2-Propanon, Asam Propanoik, 2-Furan Karbonaldehid, dan Fenol.

2. Efisiensi mortalitas ulat grayak oleh asap cair tempurung kelapa grade 3 meningkat seiring dengan pertambahan jumlah konsentrasi pada larutan uji.

3. Semakin besar kosentrasi asap cair tempurung kelapa grade 3 semakin meningkat pula nilai persen mortalitas ulat grayak. $88,89 \%$ adalah persen mortalitas ulat grayak pada konsentrasi larutan uji $7 \%$.

\section{DAFTAR PUSTAKA}

Alpian, Tiberus Agus Prayitno, Johanes Pramana Guntur Stupa dan Budiadi. 2013. Kualitas Asap Cair Batang Gelam (Melaleuca sp.). Jurnal Penelitian hasil Hutan Vol. 32 No. 2, Juni 2014:83-92

Association of Official Analytical Chemist. 1990. Official Method of Analysis. $15^{\text {th }}$ edition. Edited by Helrich $K$, Published by Assiciation of Official Analytical Chemist, Inc. Virginia USA.

Association of Official Analytical Chemist. 1995. Official Method of Analysis. $16^{\text {th }}$ edition. Assiciation of Official Analytical Chemist, Inc. Washington.

Baltibang. 2006. Hama, Penyakit dan Masalah Hara pada Tanaman Kedelai, Identifikasi dan Pengendaliannya. Bogor.

Buckle, K. A., R. A. Edwards, G. H. Fleet dan M. Wooton. 1985. IImu Pangan. Terjemahan

Ishak Isa et al. 
H. Purnomo dan Adiono. Indonesian University Press. Jakarta.

Djojosumarto, P. 2008. Pestisida dan Aplikasinya. Agromeda Pustaka, Jakarta.

Grimwood, B. E. 1975. Coconut Palm Product Tropical. London. Product Institute

Luditama, C. 2006. Isolasi dan Pemurnian Asap Cair Berbahan Dasar dan Sabut Kelapa secara Pirolisis dan Destilasi. IPB Press. Bogor

Maga, J.A. 1988. Smoke in Food Processing. CRC Press, Florida. Moeljanto. 1982. Pengasapan dan Fermentasi lkan. Jakarta. Penebar Swadaya.

Oramahi, HA, F. Diba, dan Wahdina. 2010. Efikasi Asap Cair Dari Tandan Kosong Kelapa Sawit (TKKS) Dalam Penekanan Perkembangan Jamur (Aspegillus niger. J). HTP. Tropika. Vol. 10, No, 2: 146-153.

Prasetyowati, Ayu Putri Novianty, Mutia Risa Haryuni. 2014. Pembuatan Asap Cair Dari Limbah Kulit Singkong (Manihot Esculenta L. Skin) Untuk Bahan Pengawet Kayu. Teknik Kimia No. 1, Vol. 20.
Sakung, J,. 2004. Kadar Residu Pestisida Golongan Organofosfat pada Beberapa Jenis Sayuran. Jurnal IImiah Satina.

Sudarmo, S.. 2005. Pestisida Nabati Pembuatan dan Pemanfaatanya. Kanisius. Yogyakarta. $58 \mathrm{hlm}$.

Suhariyah., Isnawati., Dan E. Ratnasari. 2013. The Effect Of Lecanicillium On Armyworms (Spedoptera Litura) Mortalyty By In Vitro Assays, Lenterabio. (2)3 : 235-257

Tentrirawe, A dan A.H. Talanca. 2008. Bioekologi dan Pengendalian hama dan Penyakit Utama Kacang Tanah. Prosiding Seminar IImiah dan penemuan Tahunan PEI PFI XIX Komisariat Daerah Sulawesi Selatan 464-471.

Tranggono, Suhardi, Setiadji, B., Darmadji, P., Supranto., dan Sudarmanto., 1996, Identifikasi Asap Cair dari Berbagai Jenis Kayu dan Tempurung Kelapa, J. IImu dan Teknologi Pangan, vol. 1, No.2: 15-24. 